\title{
Analisis Faktor Kredibilitas Website E-Commerce Indonesia Studi pada Online Purchasing
}

\author{
Muhammad Cordiaz ${ }^{\mathrm{a},}{ }^{,}$, Toni Prahasto ${ }^{\mathrm{b}}$ \\ PT. Kompas Gramedia, Jakarta \\ Jurusan Teknik Mesin, Fakultas Teknik, Universitas Diponegoro, Semarang \\ Naskah Diterima : 15 Desember 2012; Diterima Publikasi : 10 Maret 2013
}

\begin{abstract}
In the number of Internet users in Indonesia continues to increase. Internet increasingly being used for purchasing online. There are many e-commerce websites that offer goods and services online. Internet users should be able to distinguish which websites are credible before engaging in electronic commerce activities. Be an interesting question, what factors are rated by visitors of a website as an e-commerce website that is credible or reliable. Using a web-based survey methods, respondents were asked what factors support the credibility of the website in electronic commerce purchasing transactions. The respondents were Internet users. Proposed survey questions are grouped into four factors, namely, kerpercayaan factors, factors expertise, sponsorship factors and specific factors. The survey results were tested with descriptive statistic. Based on the data obtained, the Trust Factor respondents prefer e-commerce website that is trusted by his close associates, while the respondents assess the Skill Factor of websites that apply when payments online transactions through banks Indonesia is considered more reliable. In the Sponsorship Factor and Specific Factor, respondents believe the e-commerce website that does television ads in the media and managed by official institutions.
\end{abstract}

Keywords : credibility, trustworthiness, expertise, electronic commerce, online purchasing

\section{Abstrak}

Pertambahan jumlah pengguna Internet di Indonesia terus meningkat. Internet semakin sering digunakan untuk purchasing secara online. Terdapat banyak website e-commerce yang menawarkan barang dan jasa secara online. Pengguna Internet harus dapat membedakan website mana yang benar-bernar kredibel sebelum terlibat dalam melakukan aktivitas electronic commerce. Menjadi pertanyaan yang menarik, faktor apa saja yang dinilai oleh pengunjung sebuah website sebagai website e-commerce yang kredibel atau terpercaya. Metode yang digunakan dalam penelitian ini adalah metode survei berbasis web, responden ditanyakan faktor apa saja yang mendukung kredibilitas website dalam melakukan transaksi purchasing electronic commerce. Responden adalah pengguna Internet. Pertanyaan survei yang diajukan dikelompokkan dalam empat faktor, yaitu, faktor kerpercayaan, faktor keahlian, faktor sponsorship dan faktor khusus. Hasil survei diuji dengan statistk deskriptif. Berdasarkan data yang diperoleh, pada faktor kepercayaan responden lebih memilih website e-commerce yang dipercaya oleh rekan dekatnya sedangkan pada faktor keahlian reponden menilai website yang menerapkan pembayaran saat transaksi online melalui bank Indonesia dipandang lebih dipercaya. Pada faktor sponsorship dan faktor khusus, responden percaya pada website e-commerce yang melakukan penayangan iklan di media televisi dan dikelola oleh institusi resmi.

Kata kunci: Kredibilitas; Kepercayaan; Keahlian; Perdagangan elektronik; Pembelian online

\section{Pendahuluan}

Teknologi Internet terus berkembang, tercatat sampai tahun 2010 sebanyak 30 juta penduduk Indonesia sudah menggunakan Internet. Sejak tahun 2000 sampai tahun 2010 penetrasi Internet di Indonesia terhitung $12,3 \%$ atau pertumbuhan pengguna Internet naik sebesar $1400 \%$.

Besarnya pengguna Internet Indonesia dengan pertumbuhan yang terus meningkat dapat dipandang sebagai potensi ekonomi yang menjanjikan. Kegiatan ekonomi menggunakan teknologi Internet dikenal secara luas dengan istilah e-business. Antara e-business dan e-commerce memiliki kaitan erat. Ecommerce diartikan secara sempit sebagai transaksi

\footnotetext{
*) Penulis korespondensi: muhammad.cordiaz@kompas.com
}

jual beli produk, jasa dan informasi antar mitra bisnis melalui jaringan komputer, termasuk Internet.

Website e-commerce di Indonesia semakin banyak. Menurut Pengelola Domain Internet Indonesia (PANDI), dalam Azmi (2008), sampai tahun 2006 domain co.id terdaftar berjumlah 15844 domain. Berdasarkan data mulai tahun 2002 sampai tahun 2006 didapatkan rata-rata pertumbuhan jumlah domain co.id sebesar $17,56 \%$. Besarnya pertumbuhan domain tersebut jika diproyeksikan di tahun 2010, akan diperkirakan jumlah domain co.id sebesar 30.200 lebih. Jumlah website e-commerce dengan top level domain dot com (.com) yang melayani transaksi untuk pengunjung dari Indonesia tidak dapat diketahui. 


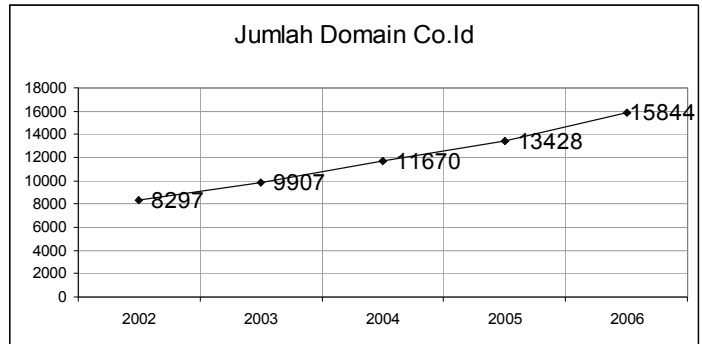

Gambar 1. Pertumbuhan Domain Co.Id Indonesia tahun $2002-2006$

Melihat secara lebih dekat perbedaan antara perilaku konsumen 'offline' dan online, paling tidak kita dapat mengenali dua permasalahan yang berbeda. Pertama konsumen online harus berinteraksi dengan teknologi sebelum mendapatkan barang atau jasa dari toko online. Fisik toko digantikan oleh lingkungan belanja elektronik atau dengan kata lain digantikan oleh sistem informasi. Hal ini menimbulkan masalah teknologi yang merupakan domain riset antara sistem informasi dan Human Computer Interaction (HCI), (O'Keefe et al., 2000). Kedua, konsumen online membutuhkan derajat kepercayaan lebih besar dibandingkan berhadapan dengan toko secara fisik. Kepercayaan akan mengurangi perasaan tidak tentu yang timbul saat berbelanja pada toko yang tidak dikenal, yang pemiliknya tidak diketahui dan kualitas produk yang tidak diketahui (Tan dan Thoen, 2001). Kedua kondisi seperti itu akan timbul pada lingkungan perdagangan elektronik. Kondisi ketidakpercayaan itu ditambah lagi dengan banyaknya penyalahgunaan e-commerce.

\section{Kerangka Teori}

Electronic commerce adalah proses pembelian, penjualan, proses transfer, atau pertukaran produk, jasa dan atau informasi melalui jaringan komputer termasuk Internet (Turban et al., 2008). Electronic commerce juga dapat didefinisikan berdasarkan lima persfektif, menurut Phan (1998) yaitu, (1) online purchasing perspective; (2) digital commnunications perpective; (3) service perspective; (4) business process perspective; dan (5) market-of-one perspective. Sudut pandang online pembelian didefinisikan sebagai sistem yang memungkinkan penjualan dan pembelian produk dan informasi melalui Internet serta jasa online lainnya, fokusnya adalah transaksi online. Perbedaan dengan pengertian e-business adalah, bahwa e-business definisi yang lebih luas dibandingkan e-commerce sehingga tidak hanya menyangkut pembelian atau penjualan barang dan jasa, tetapi juga pelayanan konsumen, kolaborasi dengan rekan bisnis dan mengadakan transaksi elektronik dalam satu organisasi. Proses pembelian produk melalui website e-commerce dapat digambarkan seperti di bawah ini.
Menurut Xiao (2004), seseorang melakukan transaksi lingkungan e-commerce melalui Internet memiliki paling tidak delapan persepsi dimensi resiko seperti Tabel 1.

Tabel 1. Definisi Delapan Resiko dalam Lingkungan e-Commerce

\begin{tabular}{|c|c|}
\hline Resiko & Keterangan \\
\hline Finansial & $\begin{array}{l}\text { Kemungkinan menderita kerugian } \\
\text { keuangan }\end{array}$ \\
\hline Sosial & $\begin{array}{l}\text { Kemungkinan memiliki kerugian yang } \\
\text { terkait dengan pengaruh nilai sosial dan } \\
\text { pandangan dari teman atau keluarga, } \\
\text { misalnya, jika tidak bertransaksi online, } \\
\text { dianggap ketinggalan jaman. }\end{array}$ \\
\hline Waktu & $\begin{array}{l}\text { Kemungkinan memiliki perasaan } \\
\text { kehilangan waktu dan menghabiskan } \\
\text { terlalu banyak waktu di lingkungan e- } \\
\text { commerce }\end{array}$ \\
\hline Kinerja & $\begin{array}{l}\text { Kemungkinan bahwa produk atau jasa } \\
\text { yang sebenarnya tidak melakukan seperti } \\
\text { yang diinginkan dan jauh dari yang } \\
\text { diharapkan. }\end{array}$ \\
\hline Fisik & $\begin{array}{l}\text { Kemungkinan kerugian secara fisik, } \\
\text { misalnya proses berbelit yang melelahkan. }\end{array}$ \\
\hline Psikologi & $\begin{array}{l}\text { Kemungkinan merasa tidak nyaman secara } \\
\text { psikologis. Misalnya merasa tidak nyaman } \\
\text { karena tidak dapat mencoba produk atau } \\
\text { jasa yang ditawarkan }\end{array}$ \\
\hline Privasi & $\begin{array}{l}\text { Kemungkinan menderita kerugian akibat } \\
\text { penyalahgunaan informasi pribadi oleh } \\
\text { toko internet. }\end{array}$ \\
\hline Keamanan & $\begin{array}{l}\text { Kemungkinan menderita kerugian akibat } \\
\text { penyalahgunaan informasi pribadi oleh } \\
\text { pihak ketiga. }\end{array}$ \\
\hline
\end{tabular}

Kredibilitas atau kredibel dalam bahasa Indonesia berasal dari kata bahasa Inggris, credible atau credibility dapat juga didefinisikan sebagai believability. Orang terpercaya (credible people) adalah orang yang dapat dipercaya; informasi terpercaya (credible information) adalah informasi yang dapat dipercaya. Jadi kredibilitas terkait dengan sesuatu tentang mutu yang dapat dililihat dari berbagai dimensi. Karena kredibilitas berkatian dengan mutu, maka tidak tergantung pada sesuatu objek, misalnya seseorang atau potongan informasi. Oleh karena itu dalam mendiskusikan kredibilitas selalu mendiskusikan persepsi kredibilitas. Kunci kredibilitas diidentifikasikan oleh banyak peneliti adalah trustworthiness dan expertise. Trustworthiness digambarkan sebagai wellintentioned, truthful, tidak memihak dan seterusnya. Dimensi kredibilitas menangkap kebaikan yang dirasakan dari sumbernya Jaman Yunani kuno menggunakan istilah etos. Expertise (keahlian) merupakan gabungan pengalaman, kepandaian, keterampilan dan pengetahuan. Kedua faktor trustworthiness dan expertise menghasilkan kredibilitas website. Kehilangan salah satu faktor tersebut berdampak kurangnya kredibilitas website (Makovsky, 2002). 
Penelitian yang dilakukan oleh Warthen dan Burkell (2002) menyatakan bahwa, terdapat empat jenis kredibilitas berdasarkan sumbernya dapat dibagi menjadi empat jenis. Pertama, presumed credibility, kredibilitas yang berasal dari asumsi pengamat, misalnya, stereotype tentang suatu hal, "penjual mobil umumnya tidak tulus," akan dapat menciptakan credibility judgment, "jangan percaya apa yang dikatakan salesman mobil." Kedua, reputed credibility, kredibilitas yang berasal dari label sumbernya. Misalnya, label "Doktor" atau "Profesor" diterima sebagai kredibilitas yang dimiliki oleh label tersebut. Ketiga, surface credibility dilekatkan oleh user berdasar pengamatan sederhana pada karakteristik penampakan, contohnya, "jangan menilai buku hanya berdasarkan sampulnya." Terakhir, keempat, experienced credibility, kredibilitas berdasar dari pengalaman pertama user dari waktu ke waktu. Hal ini paling rumit dan dapat dipertanggungjawabkan, metode merumuskan kredibilitas (Fogg, 1999; Tseng dan Fogg, 1999).

Berdasarkan struktrur dan fungsi modul yang disediakan website, kredibilitas website perusahaan dibangun dari tiga bagian kredibilitas, yaitu kredibilitas struktur website, kredibiltas layanan website dan kredibilitas pemasaran online. Kredibitas website secara keseluruhan merupakan kombinasi dan saling transfer kredibilitas dari ketiga bagian tersebut (Tan dan Wang, 2008).

Website e-commerce yang memiliki kredibilitas tinggi akan membawa kesuksesan website secara keseluruhan. Sukses website e-commerce ditentukan karena masalah kredibilitas. Pemilik website berharap orang-orang akan mengadopsi perilaku spesifik sebagai seperti, mendaftarkan informasi pribadi, membeli barang/jasa online, mengisi survei, berbagi informasi ke masyarakat, download perangkat lunak dan sebagainya. Jika pemilik website telah berhasil mempengaruhi pengunjung untuk melaksanakan tindakan ini, mereka sudah sukses dalam kredibilitas website.

Keahlian dalam teknologi sebagai penunjang kredibilitas website e-commerce diimplementasikan pada proses transaksi pembelian online dalam layer koneksi aman terenkripsi. Terdapat lima metode transaksi online (1) electronic-cash, transaksi diselesaikan melalui pertukaran mata uang secara elektronik; (2) pre-paid cards, pelanggan menggunakan kartu pra-bayar dengan jumlah nominal tertentu yang diakui oleh website merchant. Pembayaran pada website merchant akan mengurangi nilai nominal dalam pre-paid cards tersebut; (3) credit cards, sebuah sever akan memeriksa otentifikasi konsumen dan memverifikasi terhadap data bank, apakah dana yang memadai tersedia sebelum melakukan transaksi pembelian, biaya yang diposting terhadap akun konsumen dan konsumen ditagih kemudian untuk biaya dan membayar saldo rekening ke bank; (4) debit card, konsumen membayar transaksi pembelian dengan kartu debit yang masih tersedia saldo nominal kepada website ecommerce; (5) electronic checks, sebuah lembaga secara elektronik mengendapkan transaksi antara bank dan konsumen bank penjual dalam bentuk cek elektronik (Kim et al., 2009).

\section{Metodologi}

Metode penelitan yang dilakukan adalah metode survei yaitu dengan mengajukan tiga puluh satu pertanyaan kepada visitor berkaitan dengan kredibiltas berdasarkan studi literatur. Pengumpulan data menggunakan survei online SurveyMonkey.com dengan analisis menggunakan Skala Likert tujuh titik, 1, 2, 3, 4, 5, 6, dan 7. Angka 1 untuk pernyatan dengan jawaban 'Sangat Tidak Percaya', angka 2 untuk pernyataan dengan jawaban 'Tidak Percaya', angka 3 untuk pernyataan 'Agak Tidak Percaya', angka 4 untuk pernyataan dengan jawaban 'Netral', angka 5 untuk pernyataan 'Agak Percaya', angka 6 untuk pernyataan dengan jawaban 'Percaya' dan angka 7 untuk pernyataan dengan jawaban 'Sangat Tidak Percaya'. Survei disebarkan di Internet melalui social networking seperti Facebook dan beberapa mailing list. Data yang diperoleh dinotasikan kemudian diolah menggunakan SPPS. Pertama kali data diuji reliabitasnya untuk mengetahui kehandalan konstruk yang diajukan. Reliabilitas diuji statistik dengan membandingkan nilai Cronbach Alpha, apabila lebih besar dari 0,6 variabel atau konstruk tersebut handal atau reliabel. Uji selanjutnya adalah uji validitas untuk untuk mengukur valid atau tidaknya kuesioner. Selanjutnya data diuji dengan uji Faktor Analisis dengan Rotasi Faktor Varimax untuk mengetahui korelasi antar sejumlah besar konstruk atau variabel.

\section{Hasil dan Pembahasan}

Survei diikuti oleh 109 responden melalui web based survey, berlangsung mulai Oktober sampai November 2011. Profil tingkat pendidikan responden terbanyak adalah tingkat pendidikan diploma/S1, berjenis kelamin laki-laki dengan umur antara lebih dari 25 tahun sampai 35 tahun, sebanyak 33 orang atau sebesar $47,1 \%$ dari seluruh jumlah responden laki-laki dan 30,2\% dari seluruh responden laki-laki dan perempuan. Kelompok responden kedua terbanyak adalah kelompok responden perempuan dengan umur antara lebih dari 25 tahun sampai 35 tahun dengan tingkat pendidikan diploma/S1, sebanyak 20 orang atau sebesar $60,6 \%$ dari seluruh jumlah responden perempuan dan 18,3\% dari seluruh jumlah responden laki-laki dan perempuan. Tidak terdapat responden berumur lebih dari 55 tahun. Tidak terdapat responden dengan tingkat pendidikan $\mathrm{SD} / \mathrm{SMP}$ sederajat. 
Dari total 109 respoden, 41,3\% orang responden mengaku membeli produk atau jasa melalui internet sebanyak lebih dari empat kali. Kelompok responden ini merupakan kelompok responden terbanyak, kelompok responden kedua adalah kelompok responden yang membeli produk atau jasa melalui internet satu atau dua kali, sebanyak 23,9\%. Kelompok responden yang membeli produk tiga sampai empat kali sebanyak 15,6\%, merupakan kelompok responden paling sedikit. Jumlah responden yang tidak pernah melakukan pembelian produk atau jasa melalui internet sebanyak 19,3\% responden.

Reponden dengan pekerjaan pegawai swasta/BUMN merupakan kelompok terbanyak melakukan pembelian produk atau jasa melalui internet, yaitu sebanyak $22,9 \%$ reponden dengan pembelian lebih dari empat kali. Kelompok responden dengan pekerjaan pegawai swasta/ BUMN merupakan kelompok kedua terbanyak yang melakukan pembelian produk atau jasa melalui internet, sebanyak $10,1 \%$ responden. Kelompok responden dengan pekerjaan pegawai swasta/BUMN merupakan kelompok pekerjaan yang melakukan pembelian produk atau jasa melalui internet terbanyak. Kelompok pekerjaan kedua yang yang paling banyak melakukan pembelian produk atau jasa melalui internet adalah kelompok pekerjaan wiraswasta dan pegawai negeri (TNI/Polri/PNS).

Suatu kuesioner dikatakan reliabel atau handal jika jawaban seseorang terhadap pernyataan adalah konsisten atau stabil dari waktu ke waktu (Ghozali, 2009, h.45, 46). Hasil uji Cronbach Alpha terhadap indikator atau pertanyaan yang diajukan disajikan dalam Tabel 2.

Tabel 2. Hasil uji reliabilitas

\begin{tabular}{llcc}
\hline No. & \multicolumn{1}{c}{ Variabel } & $\begin{array}{c}\text { Cronbach } \\
\text { Alpha }\end{array}$ & Keterangan \\
\hline 1 & Faktor & 0,894 & Valid \\
& Kepercayaan & & \\
2 & Faktor Keahlian & 0,902 & Valid \\
3 & Faktor Sponsor & 0,802 & Valid \\
4 & Faktor Khusus & 0,859 & Valid \\
\hline
\end{tabular}

Suatu kuesioner dikatakan valid jika pertanyaan pada kuesioner mampu untuk mengungkapkan sesuatu yang akan diukur oleh kuesioner tersebut. Untuk menguji apakah masing-masing indikator atau pertanyaan kuesioner valid atau tidak, kita lihat tampilan output Cronbach Alpha pada kolom Correlated Item - Total Correlation pada semua indikator atau pertanyaan kuesioner dibandingkan dengan nilai r-table. Jika $r$ hasil perhitungan bernilai positif dan lebih besar dari r-table, yaitu 0,3109 maka indikator atau pertanyaan tersebut dinyatakan valid (Ghozali, 2009, h.49).

Data dari kuesioner tersebut dianalisa dengan menggunakan statistik deskriptif. Statistik deskriptif variabel penelitian digunakan untuk memberikan gambaran tentang tanggapan responden terhadap variabel-variabel penelitian yang terdapat dalam Faktor Kepercayaan, Faktor Keahlian, Faktor Sponsorship dan Faktor Khusus.

Hasil perhitungan statistik deskriptif variabel Faktor Kepercayaan diperoleh nilai lebih besar dari 5 sebanyak sembilan variabel dan dua variabel lebih besar dari 4. Nilai mean terendah ada pada variabel K7, "Website yang menyediakan nomer telepon seluler yang dapat dihubungi." Nilai mean tertinggi ada pada variabel K11, "Website yang direkomendasikan oleh rekan dekat Anda." Hasil perhitungan statistik deskriptif variabel Faktor Keahlian terdapat nilai mean yang lebih kecil dari 5 sebanyak tiga variabel. Terdapat delapan variabel memiliki nilai mean lebih dari 5. Nilai mean terendah Faktor Keahlian terdapat pada variabel H11, "Website yang memiliki link yang tidak dapat ditelusuri (dead link)." Nilai mean tertinggi Faktor Keahlian terdapat pada variabel H1, "Pengelolaan website yang merespon cepat pertanyaan dan komentar pengunjung."

Hasil perhitungan statistik deskriptif variabel Faktor Sponsorship terdapat nilai mean yang lebih kecil dari 5 sebanyak dua variabel. Terdapat satu variabel memiliki nilai mean lebih dari 5. Nilai mean terrendah Faktor Sponsorship terdapat pada variabel S2, "Website yang menampilkan iklan dari Google Adsense." Nilai mean tertinggi Faktor Sponsorship terdapat pada variabel S1, "Website yang diiklankan melalui televisi di Indonesia." Hasil perhitungan statistik deskriptif variabel Faktor Khusus. Terdapat nilai mean yang lebih kecil dari 5 sebanyak dua variabel. Terdapat empat variabel memiliki nilai mean lebih dari 5. Nilai mean terendah Faktor Khusus terdapat pada variabel L6, "Website sukar dinavigasi." Nilai mean tertinggi Faktor Sponsorship terdapat pada variabel L1, "Website dikelola oleh institusi resmi." Nilai mean variabel selengkapnya disajikan dalam Gambar 2.

Semakin tinggi nilai mean memperlihatkan variabel semakin dipercaya oleh responden. Nilai tertinggi mean yang diperoleh adalah 5,74. Semakin rendah nilai mean variabel semakin pernyataan tersebut tidak dipercaya menurut responden. Nilai mean terendah variabel pernyataan yang diperoleh adalah 3,08.

Selanjutnya tiga puluh satu variabel tersebut diuji Faktor Analisis dengan Rotasi Faktor Varimax. Tujuan utama dari Analisi Faktor adalah mendefinisikan struktur suatu data matrik dan menganalisis struktur saling hubungan (korelasi) antar sejumlah besar variabel dengan cara mendefinisikansatu set kesamaan variabel atau dimensi dan sering disebut dengan faktor. Dengan menggunakan analisis faktor, dapat diidentifikasikan dimensi suatu struktur dan kemudian menentukan sampai seberapa jauh setiap variabel dapat dijelaskan oleh setiap dimensi. Begitu dimensi dan penjelasan 
setiap variabel diketahui, maka dua tujuan utama Analisis Faktor dapat dilakukan yaitu data summarization dan data reduction. Jadi Analisis Faktor ingin menemukan suatu cara meringkas (summarization) informasi yang ada dalam variabel asli (awal) menjadi satu set dimensi baru atau variate (factor).

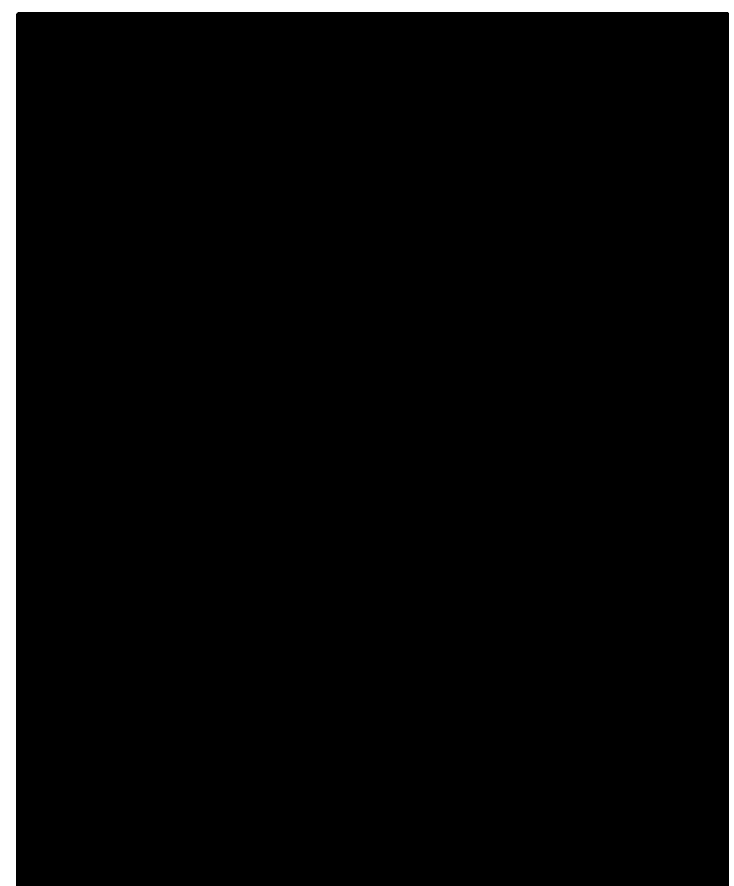

Gambar 2. Nilai mean variabel survei

Kesebelas variabel Faktor Kepercayaan yang dianalisis ternyata hasil ekstraksi komputer menjadi dua faktor, yaitu nilai eigen value lebih besar dari 1 . Faktor 1 mampu menjelaskan variasi sebesar $49,569 \%$ variasi yang ada, faktor 2 mampu menjelaskan variasi sebesar 9,718\%. Kedua faktor tersebut secara keseluruhan mampu menjelaskan $59,287 \%$ variasi yang ada. Kesebelas variabel Faktor Keahlian yang dianalisis ternyata hasil ekstraksi komputer menjadi dua faktor, yaitu nilai eigen value lebih besar dari 1. Faktor 1 mampu menjelaskan variasi sebesar $54,913 \%$ variasi yang ada, faktor 2 mampu menjelaskan variasi sebesar 12,134\%. Kedua faktor tersebut secara keseluruhan mampu menjelaskan $67,047 \%$ variasi yang ada. Ketiga variabel Faktor Sponsorship yang dianalisis ternyata hasil ekstraksi komputer hanya menjadi satu faktor, yaitu nilai eigen value lebih besar dari 1. Faktor 1 mampu menjelaskan variasi sebesar $71,674 \%$ variasi yang ada, faktor 2 mampu menjelaskan variasi sebesar $15,070 \%$ dan faktor 3 mampu menjelaskan variasi sebesar 13,283. Ketiga faktor tersebut secara keseluruhan mampu menjelaskan $100,00 \%$ variasi yang ada. Keenam variabel Faktor Khusus yang dianalisis ternyata hasil ekstraksi komputer hanya menjadi satu faktor, yaitu dengan nilai eigen value lebih besar dari 1. Faktor 1 mampu menjelaskan variasi sebesar $60,049 \%$ variasi yang ada, faktor 2 mampu menjelaskan variasi sebesar $14,846 \%$, faktor 3 mampu menjelaskan variasi sebesar $9,740 \%$, faktor 4 mampu menjelaskan variasi sebesar $6,815 \%$, faktor 5 mampu menjelaskan variasi sebesar $4,637 \%$ dan faktor ke enam mampu menjelaskan variasi 3,912\%. Keenam faktor tersebut secara keseluruhan mampu menjelaskan $100,00 \%$ variasi yang ada.

Dalam kelompok variabel Faktor Kepercayaan, responden berpendapat bahwa website yang dipercaya oleh rekan dekatnya meningkatkan kredibilitas website tersebut. Ulasan produk atau layanan yang diberikan oleh suatu website tertentu tersebut di Internet dapat disampaikan diantaranya pada status di media sosial, tulisan blog, mailing list, forum diskusi dan ulasan produk. Penyajian online ulasan produk atau jasa memudahkan diakses oleh banyak orang, sehingga informasi tersebut makin efektif tersebar. Seorang konsumen dapat mengenali ulasan dan tanggapan yang baik dan buruk suatu produk. Perhatian konsumen tidak hanya terpusat pada nilai ulasan tertinggi produk tapi juga memperhatikan reputasi penulis dan ulasannya. Di internet pengunjung merespon dengan baik ulasan yang mendapat tanggapan tinggi dan pengulas dengan reputasi baik.

Ulasan dan tanggapan antar pengunjung website e-commerce didukung oleh pengelola sehingga menjadikan website e-commerce bersifat lebih sosial dalam arti melibatkan pelanggan dan calon pelanggan. Aktifitas pengunjung untuk berinteraksi meningkatkan trafik website yang menjadi titik awal pembeli online. Website yang memiliki basis jaringan sosial menjadi lebih populer, calon pelanggan yang tidak memiliki informasi lengkap tentang suatu produk atau jasa sering kali menggunakan pendapat pelanggan sebelumnya. Kepercayaan pada produk mendorong calon pelanggan melakukan transaksi di dalam website (Kim dan Srivastava, 2007).

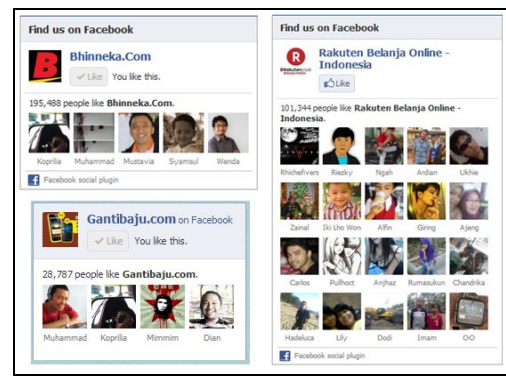

Gambar 3. Facebook Social Plugins di website e-commerce Indonesia

Dalam waktu lima tahun terakhir, e-commerce generasi pertama telah berkembang menjadi ecommerce generasi kedua. Generasi pertama ecommerce dikenal dengan istilah $3 \mathrm{Cs}$, yaitu tiga hal yang diperhatikan dalam mengelola kesuksesan website e-commerce. Tiga $\mathrm{C}$ hal tersebut, adalah 
content, community dan commerce. Generasi kedua e-commerce, tiga hal tersebut berkembang menjadi 7 $\mathrm{Cs}$, dengan empat hal lainnnya yaitu, communication, connectivity, collaboration, customization (Hazari, 2012). Website e-commerce dapat menambahkan fitur komunitas agar mendukung interaksi sosial antar pengunjungnya. Beberapa produk scripting ecommerce open source menawarkan content management system e-commerce (CMS) yang sudah tersedia fitur untuk membangun komunitas, misalnya pada CMS Magento, Prestashop, OpenChart, VirtueMart dan lainnya. Sekalipun fitur komunitas belum menjadi fitur standar saat pertama kali CMS tersebut dikonfigurasi, namun fitur tersebut mudah untuk ditambahkan ke dalam sistem CMS ecommerce dalam bentuk module, plugin atau component.

Fitur komunitas diharapkan dapat menciptakan lingkungan yang seusai bagi visitor dan pelanggan agar merasa menjadi bagian dari website e-commerce dan turut berpartisipasi. Beberapa bentuk fitur komunitas website e-commerce adalah ruang diskusi atau forum, ruang chat dan newsletter (Fiore, 2001). Keterikatan pelanggan dan visitor dengan website ecommerce tanpa melepaskannya dengan lingkungan sosialnya di Internet diakomodir dengan disediakannya API (Application Programming Interface) oleh website-website media sosial seperti Twitter.com dan Facebook.com.

Faktor Keahlian yang menurut responden lebih dipercaya dalam transaksi melalui website ecommerce di Internet adalah website yang menyediakan pembayaran melalui sejumlah bank lokal Indonesia. Responden menentukan bank yang digunakan dalam proses pembelian adalah Bank BCA (PT. Bank Central Asia, Tbk), Bank Mandiri (PT Bank Mandiri Persero, Tbk) dan Bank BNI (PT Bank Negara Indonesia Persero Tbk). Pembayaran yang dilakukan oleh responden masih melalui cara sederhana yaitu dengan transfer ke rekening penjual dilanjutkan dengan konfirmasi melalui SMS atau email. Sekalipun pembayaran tersebut masih sederhana, namun responden lebih mempercayai cara tersebut. Pembayaran transaksi puchasing yang disediakan oleh website e-commerce terdapat dalam berbagai metode, mulai dari yang paling sederhana sampai yang tingkat lebih lanjut.

Faktor Sponsorship yang banyak dipilih responden karena meningkatkan kepercayaan terhadap website e-commerce adalah website yang diiklankan di televisi Indonesia. Media elektronik televisi memiliki kelebihan dalam menyampaikan informasi dibanding media lainnya. Melalui media televisi sedikit informasi audio visual disodorkan langsung ke hadapan pemirsa. Meskipun keterlibatan pemirsa terhadap informasi rendah, namun banyak responden menilai informasi tersebut dapat meningkatkan kepercayaan pemirsa terhadap website e-commerce yang diiklankan (Park et al, 2008).
Faktor Khusus yang menurut responden turut mempengaruhi kepercayaan sebuah website ecommerce adalah website tersebut dikelola oleh institusi resmi. Salah satu halaman dalam website terdapat informasi yang menerangkan siapa pengelola dan informasi mengenai website ecommerce tersebut. Sebuah website e-commerce lazim menyertakan halaman "About Us" atau "Tentang Kami" dan yang sejenis. Informasi pengelola tersebut terdapat dalam halaman"About Us" atau "Tentang Kami". Lokasi penempatan informasi tersebut berada di halaman depan website e-commerce, dapat di bagian atas maupun di bagian bawah.

\section{Kesimpulan}

Berdasarkan analisa yang dilakukan terhadap data yang diperoleh dari survei analisis faktor kredibilitas website e-commerce Indonesia studi pada online purchasing adalah sebagai berikut, faktor kepercayaan yang mempengaruhi kredibilitas website adalah informasi kredibilitas website tersebut dari teman yang didapat di internet. Sedangkan pada faktor keahlian metode pembayaran berupa transfer rekening di Indonesia masih merupakan teknis pembayaran yang dapat dipercaya oleh pelanggan. Pada faktor sponsorship pernyataan website ecommerce juga perlu menayangkan iklan di televisi sebagai bagian dalam membangun kepercayaan pelanggan dan faktor khusus pernyataan website dikelola oleh institusi resmi mampu meningkatkan kepercayaan visitor website e-commerce.

\section{Daftar Pustaka}

Azmi, R., 2008. The Grid: Teknologi Internet di Masa Mendatang. Website:http://perpustakaan.balitbang.kominfo.go .id/perpustakaan/index.php? $\mathrm{p}=$ show detail\&id $=2$ 30 diakses tanggal 5 Oktober 2010.

Fiore, F., 2001. The Three C's of E-Commerce, 2001.

Website:http://www.peachpit.com/articles/article. aspx? $\mathrm{p}=23997$, diakses tanggal 13 September 2012.

Fogg, B.J., and Tseng, H., 1999. The elements of computer credibility. Paper presented at the Conference on Human Factors and Computing Systems, Pittsburgh, PA, May 15-20, 1999

Ghozali, I., 2009. Aplikasi Analisis Multivariate dengan Program SPSS. Badan Penerbit Universitas Diponegoro.

Hazari, S., 2012. The Evolution of eCommerce in Internet $2012 . \quad$ Time, Website: http://www.sunilhazari.com/education/documents / evolution.htm, diakses tanggal 11 September 2012 
Kim, Y., Ae, Jaideep, S., 2007. Impact of social influence in ecommerce decision making. Proceedings of the ninth international conference on Electronic commerce, 293-302. Website: http://dl.acm.org/citation.cfm?id=1282157, diakses tanggal 9 September2012.

Kim, C., Tao W. S., Namchul, K., Ki-Soo, 2009. An empirical study of customers' perceptions of security and trust in e-payment systems. Electronic Commmerce Research and Application. Website: ftp://163.25.117.117/gyliao/SecurityLiterature/An $\% 20$

empirical $\% 20$ study $\% 20$ of $\% 20$ customers $\% 20$ perc eptions $\% 20$ of $\% 20$ security $\% 20$ and $\% 20$ trust $\% 20$ in $\% 20$ e-payment $\% 20$ systems.pdf, diakses tanggal 13 Oktober 2012

Park, T., Shenoy, R., Salvendy, G., 2008. Effective Advertising on mobile phone: a literature review and presentation of results from 53 case studies. Behaviour \& Information Technology, Vol. 27, No. 5, September - October 2008, 355 - 373. Website: http://itu.dk/ rkva/2011-SpringEB22/readings/Effective $\% 20$

advertising $\% 20$ on $\% 20$ mobile $\% 20$ phones $\% 20 a \%$ 20literature\%20review....pdf, diakses tanggal 23 Oktober 2012. by Stanford Persuasive Technology Lab and Makovsky \& Company

Tan, C., Jun, W. The Model of Online Purchasing Behavior Based on Website's Credibility and Its Inspiration for Enterprises dalam Proceedings of the 2008 International Conference on Information Management, Innovation Management and Industrial Engineering - Volume 02, halaman 506 - 511. Diakses dari http://portal.acm.org/citation.cfm?id=1491037, tanggal 2 November 2010

Warthen, C., Nadine, B., J. Believe It or Not: Factors Influencing Credibility on the Web, 2002. Journal of The American Society for Informatin Science and Technology, 53(2):134 - 144. 2002.

Xiao, L., 2004. Empirical Studies of Consumer Online Shopping Behavior. Website: http://scholarbank.nus.edu.sg/bitstream/handle/ 10635/14358/LiuXiao.PDF?sequence=1, diakses tanggal 22 November 2012

Standford-Makovsky, 2002. Investigating What Makes Web Credible Today. A Research report 